EA 4272

\title{
How important is security in the choice of employment? Evidence from European countries
}

\author{
Frédéric Salladaré $\left({ }^{*}\right)$ \\ Boubaker Hlaimi $\left.{ }^{* *}\right)$ \\ François-Charles Wolff $\left.{ }^{* * *}\right)$
}

$2010 / 23$

(*) LEMNA - CREM - CNRS - Université de Rennes 1

$\left.{ }^{* *}\right)$ LEST CNRS - Université de Rennes 1

$\left(^{* * *}\right)$ LEMNA - CNAV - INED - Université de Nantes

Laboratoire d'Economie et de Management Nantes-Atlantique Université de Nantes

Chemin de la Censive du Tertre - BP 52231

44322 Nantes cedex 3 - France

www.univ-nantes.fr/iemn-iae/recherche

Tél. +33 (0)2 40141717 - Fax +33 (0)2 40141749 


\title{
How important is security in the choice of employment? Evidence from European countries ${ }^{\#}$
}

\author{
Frédéric Salladarré*
}

\author{
Boubaker Hlaimi** $^{* *}$
}

\author{
François-Charles Wolff ${ }^{* * *}$
}

September 2010

\begin{abstract}
Is job security important for workers when choosing a job? Using comparative data among 18 European countries, this paper investigates the influence of job security in the choice of employment. Our empirical analysis evidences significant cross-country differences in the importance attributed to job security, which is influenced by both individual and employment characteristics. When comparing the perceived job security and its importance in the choice of employment, we find that temporary workers are less sensitive to job security when choosing their job.
\end{abstract}

Keywords: Perceived job security; European labour markets

\footnotetext{
\# We are indebted to participants of the Small Group Meeting in Leuven for helpful comments. The usual disclaimer applies.

* CREM-CNRS \& LEMNA, Université/IUT de Rennes 1, Campus de Beaulieu, Avenue du Général Leclerc, CS 44202, 35042 Rennes Cedex ; Email of the corresponding author: frederic.salladarre@univ-rennes1.fr ${ }^{* *}$ LEST CNRS and University of Rennes, France. E-mail : boubaker.hlaimi@univ-rennes1.fr

${ }^{* * *}$ LEMNA, University of Nantes; CNAV and INED, Paris, France. E-mail : wolff@sc-eco.univ-nantes.fr
} 


\section{Introduction}

The debate in Europe around flexicurity has brought to light several issues over the last decade (European Commission, 2007). Among the most important issues is the question of whether people are ready or not to accept more flexibility in the labour market in exchange for greater security. On the one hand, there is a demand for greater flexibility in the labour markets in order to increase economic competitiveness and thus to improve growth. On the other hand, employees need security to maintain their jobs skills and to move up in their current occupation. In a context where employment trajectories are increasingly characterized by more uncertainty, paid work and its stability are key issues for the majority of individuals ${ }^{1}$.

Several recent studies have analysed the concept of perceived job insecurity (Green et al., 2001; Böckerman, 2004; Erlinghagen, 2008). It has been shown that perceived job insecurity may have detrimental effects on, among other factors, employee well-being and health. (Bohle et al., 2001; Green et al., 2001). Blanchflower and Oswald (1999), Sverke et al. (2002) and D'Addio et al. (2003) find a negative correlation between perception of job insecurity and job satisfaction. Because of its detrimental consequences on psychological and physical well-being and family life (De Witte, 1999; Westman et al., 2001), perceived job insecurity may also reduce organisational performance. Furthermore, the business cycles, economic conditions and labour market institutions such as employment protection legislation and levels of unemployment insurance benefit have an incidence on perceived job security (Clark and Postel-Vinay, 2009).

Interestingly, all these studies are based on the concept of perceived job security. However, a few of them consider job security in relation to its importance within the system of values among the workforce (see Greenhalgh and Rosenblatt, 1984; Ashford et al., 1989; Greenhalgh and Rosenblatt, 2010). Analysing perceived job security makes sense only if it is considered as an important value by employees in relation to other values like career prospects, wage level or work-life balance. The purpose of our paper is to analyse the factors that explain the importance of job security and the question of international differences in the importance attributed to job security. For that purpose, we undertake an empirical study of these factors with a focus on the role of job security on employment choice and on its relative magnitude among a large sample of European countries.

Our empirical analysis is based on the data from the European Social Survey conducted in 2004/2005. Our particular interest is the extent to which job security and its importance differ among the various countries and how these two concepts are articulated. We study whether the importance of job insecurity in the choice of employment is purely 
subjective or whether it is related to certain characteristics of workers and of their current occupation. We also compare perceived security among temporary and permanent workers and the importance they attribute to it.

Our empirical work has both academic and political implications. An increasing amount of research in various disciplines has analysed the flexibility/security trade-off. The new concept of flexicurity has emerged as a middle ground between these two apparently antagonist concepts (Madsen, 2004, Oorschot, 2004, Wilthagen and Tros, 2004, Wilthagen et al., 2004) ${ }^{2}$. According to European Commission (2007), flexicurity strategy objectives are attained when employees consider that job security is less important due to the fact that it is easy to find a job and that job security does not matter as they will change careers during their working life.

The remainder of our paper is organized as follow. In Section 2, we briefly review the previous studies on perceived job security and discuss the link between perceived job security and its importance. We also develop some theoretical hypothesises. We present the data and methods in Section 3, our main empirical results being commented in Section 4. Finally, Section 5 concludes with a discussion.

\section{Theoretical background}

As defined by Erlinghagen (2008) and Clark and Postel-Vinay (2009), 'job security' refers in this paper to the situation where employees perceive the continuance of their employment not to be under threat. The importance of job security is used to express the degree to which employment continuity is assessed as important when choosing a job. These two notions, perceived job security and its importance, are subjective and they have to be distinguished from objective indicators of insecurity such as levels of layoffs and dismissals or measurements of job tenure (De Witte and Näswall, 2003).

In the psychological literature, the debate has been centered on job insecurity. This latter has primarily been analysed as a purely cognitive phenomenon including some sense of powerlessness in face of this threat (Greenhalgh and Rosenblatt, 1984; Ashford et al., 1989). This perceived likelihood of job loss depends on immediate organizational circumstances. More recently, the affective job insecurity has been conceptualized as worry or anxiety regarding the outcome or evaluation of job loss (Sverke and Hellgren, 2002). Moreover, previous works argue that cognitive job insecurity is a major determinant of affective job insecurity (Borg and Elizur, 1992). 
Following Anderson and Pontusson (2007), we suppose that individuals take into account several objective factors when estimating the probability that they might keep their current job. The importance attached to job security is likely to depend on these factors. Perceived job security and its importance are supposed to be the outcome of an individual assessment process in which both microeconomic and macroeconomic factors and labour market institutions have been taken into account (Coleman 1986).

\subsection{Perceived job security: previous related studies}

At the micro level, recent studies show that perceived job security is linked to demographic, economic and employment factors. Age has been found to be inversely related to perceived job security (Postel-Vinay and Saint Martin, 2005; Blanchflower and Oswald, 1999), probably because unemployment costs increase with age given the decrease in the reemployment rate. Studies do not find any effect of gender (Erlinghagen, 2008; Green et al., 2001). Following OECD (2003), while perceived job security increases with education level.

A second set of factors that is expected to affect perceived job security is the family situation. As stated by Böckerman (2004), marital status is likely to influence perceived job security. Being married can be considered by employers as a positive signal of stability, which is likely to increase perceived job security. The presence of children living within the household may also affect perceived job security. Working hours could be reduced due to parental childcare responsibilities with an accordant decrease in perceived job security (Anxo, 2003). However, Clark and Postel-Vinay (2009) find no effect associated to both marital status and presence of children.

Another set of characteristics which should affect subjective job security are those related to employment history, for instance previous spells of unemployment, seniority, or temporary contracts. Several studies show that previous periods of unemployment reduce perceived job security (Erlinghagen, 2008; Green et al., 2001). Individuals who have experienced a period of unemployment may be 'scarred' by their experience. Concerning seniority, a long tenure may be interpreted as a favourable signal increasing perceived job security. Böckerman (2004) and Postel-Vinay and Saint Martin (2005) find that workers with greater seniority feel more protected. Temporary employees report lower job security than permanent employees (Erlinghagen, 2008; Green et al., 2001). According to the OECD (2002), temporary employment is less secure and provides fewer career prospects and training opportunities. 
Temporary employment may also hamper skills-development and wage growth when firm-specific training exclusively concerns permanent workers. According to Böckerman (2004), the perception of job security is positively related to the presence of a part-time contract. On the one hand, working part-time may be a constraint for workers who would prefer having a full-time job and it may be associated with bad working conditions. This would imply a lower perceived job security. Nonetheless, if constrained part-time jobs are perceived as a second choice, the costs associated with the lost of such job may also be lower. On the other hand, part-time may be chosen (for instance, public servants are characterized by a high proportion of part-timers) and the perceived job security may be higher.

According to Davis and Haltiwanger (1999), the turnover decreases with the size of the firm, so that the perceived job security is expected to be negatively related to the firm size. Concerning the economic sectors, the perception of job security has been found lower within manufacturing industries than in the service sector (Böckerman, 2004; Aaronson and Sullivan, 1998).

Previous studies have also sought to study national differences in perceived job security using macroeconomic and institutional indicators (Böckerman, 2004; Erlinghagen, 2008; Postel-Vinay and Saint Martin, 2005; Clark and Postel-Vinay, 2009). Since perceived job security is a subjective concept, external factors and macroeconomic and institutional settings may have an influence on the way employees make their individual assessment of their job security. National unemployment levels may be considered as a proxy for the state of the economy. This is likely to affect the perception of the probability of job loss, especially in countries where declining sectors characterised by higher unemployment rates still employ a relatively high proportion of the workforce. According to Böckerman, (2004), the average unemployment rate is negatively associated with perceived job security.

Using the OECD employment protection index based on the strength of the legal framework governing hiring and firing of workers ${ }^{3}$, Clark and Postel-Vinay (2009) find a negative relationship between perceived job security and the strictness of employment protection legislation across countries. Greater employment protection tends to reduce the flexibility of the labour market. As it is more difficult to fire, employers may be less inclined to hire. We also consider the potential roles of unemployment insurance benefits and active labour market policies on perceived job security. In line with the results of Clark and PostelVinay (2009), in countries where unemployment insurance generosity is high, individuals should perceive a higher job security since higher unemployment insurance generosity supports employees. The goal of active labour market policies is to facilitate transitions from 
school to first job, between different jobs and from unemployment to employment by improving the functioning of the labour market in diverse ways ${ }^{4}$. Then, a positive relationship between perceived job security and active labour market policies is expected.

Beyond these empirical studies which have provided interesting predictions about job security, we now analyse the determinants of job security in relation to its importance within the system of values among employees.

\subsection{Perceived job security and the importance of job security}

Perceived job security is likely to explain the importance that individuals attribute to security in their choice of employment. Restructurations, layoffs and the reduction of permanent contracts in paid employment are some factors that might reduce perceived job security. According to Greenhalgh and Rosenblatt (1984:443), "it would be rational for employees worried about continuity of employment to seek more-secure career opportunities". Employees who have a high probability of job loss might value job security more than others when choosing a job or career. Accordingly, the employee's well-being is related to the potential risk of losing their job in the presence of incomplete insurance against shocks. The so-called replacement rate of unemployment insurance is almost always less than $100 \%$ (Böckerman, 2004). So, we would expect employees to search for more security in their choice of employment when their perceived job security is weak.

\subsection{The importance of job security}

Individual factors such as age, gender, and human capital are expected to influence the importance of job security. We expect a negative correlation between age and the importance of job security in the choice of employment. Older workers will certainly be less demanding as they face lower exit rates of unemployment. Concerning gender, men are likely to report a higher level of importance allotted to job security because of their traditional social role of 'breadwinner' (Lewis, 2002). Highly educated employees report a lower importance of job security as it appears easier for them to find a job in the case of unemployment.

The second set of factors that would be expected to affect the importance of job security is the family situation. Roles, expectations and specialisations may differ according to the family structure. Marital status is expected to influence the importance of job security. If a household is made up of two wage-earners, then job security might be less important since marriage provides insurance through income pooling. The presence of children living within the household may affect the importance of job security. Because of their financial 
responsibilities towards their offspring, the importance the parents give to job security may be increased.

Another set of characteristics which would be expected to affect the importance of job security is related to employment history. Workers who have experienced a period of unemployment can be 'scarred' by this experience (Arulampalam et al., 2001). This could increase the importance given to job security. Also, the importance of job security is expected to be positively correlated with the length of job tenure. High seniority often means a longterm relationship between employers and employees, which may imply that workers offer loyalty and increased effort in exchange for security and stability. Part-time employment can improve the work-life balance. For some people, work-life balance may prevail over the importance attributed to job security, so that the latter could be lower for such people.

Permanent and temporary employees are likely to have different expectations regarding the importance of job security ${ }^{5}$. Some researchers have examined the effect on opportunities at labour market entry via temporary jobs (see Nunziata and Staffolani, 2007). On the one hand, having experienced lower job security, the importance of job security may be increased and temporary employment may be seen as a 'stepping stone' to permanent employment by acting as an extended probationary period. One the other hand, in a 'job shopping' scenario, this importance would be reduced for temporary workers.

Concerning the role of the firm size, the importance of job security is expected to be higher in large sized-firms due to the higher turnover. Concerning economic sectors, the importance of job security would be expected higher in primary and secondary sectors than in the tertiary sector due to the economic situation, the weight of the primary and secondary sectors in the value-added declining from several decades.

At a macro level, the state of the economy and labour market institutions may affect the importance of job security, through perceived job security. A high rate of unemployment is likely to be worrying, pushing employees to reconsider their job security. Conversely, high levels of unemployment benefit may have a reassuring impact on employees who are then less inclined to worry about their job security. As a high rate or a low rate of unemployment is likely to affect the individual perception of job insecurity, these variables are expected to influence the importance attributed to job security in the choice of employment.

Still at the macro level, other contextual factors may have an incidence on how much job security matters to workers. The underlying economic situation is likely to affect perceived job security and thus the importance attributed to it. A high national unemployment 
rate is expected to increase the importance of job security, while employment policies should have the opposite effect.

Such labour market programmes should also increase the flexibility of the labour market and then reduce the importance of job security among the employed. Clearly, a generous Welfare state system offering a high level of decommodification (especially for the unemployed) will lessen the importance attributed to job security. The perceived importance of job security should be negatively associated with higher degrees of labour market regulation, especially in the case of employment protection legislation.

To summarize, the importance of job security in choice of employment is expected to be related to both individual and current job characteristics, and also to the current institutional context. In what follows, we investigate importance attributed to job security in the choice of employment using comparative European data. We particularly focus on the possible role of the national context when explaining differences between European countries.

\section{Data and methods}

For our empirical analysis, we use data from the second wave of the European Social Survey (henceforth ESS) conducted in 2004-2005. The ESS project is jointly funded by the European Commission, the European Science Foundation and academic funding bodies in each participating country. It involves strict random probability sampling, a minimum target response rate of $70 \%$ and rigorous translation protocols. One advantage of the ESS is that there is ex ante harmonization of the questionnaire between countries. Individuals have been surveyed using a standardised face-to-face questionnaire.

Our sample includes 45,681 individuals and it covers 18 countries: Austria, Belgium, Switzerland, Germany, Denmark, Spain, Finland, France, the United Kingdom, Greece, Ireland, Iceland, Luxembourg, the Netherlands, Norway, Portugal Sweden and Slovenia ${ }^{6}$. The main purpose of this survey was to measure changes and persistence in a range of social and demographic characteristics, attitudes and behaviour patterns. Its core module contains questions on occupation and social structure, social exclusion, religious affiliation, ethnic and national identity, political trust, party affiliation, multilevel governance and voting attitudes, media consumption, value orientations and labour market participation. The survey includes about 500 questions related to employment, working conditions and the socio-demographic characteristics of the respondents.

Respondents were asked about the importance attributed to job security through the following question (G111): "For you personally, how important do you think a secure job 
would be if you were choosing a job?". Possible answers were 'not important at all', 'not important', 'neither important nor unimportant', 'important', and 'very important'. Respondents were also asked about their feelings regarding their cognitive job security (question G66): "Please tell me how true the following statement is about your current job: my job is secure". Possible answers were 'not at all true', 'a little true', 'quite true', and 'very true'. We test the influence of the following covariates on these two outcomes: gender, age (4 modalities), marital status ( 2 modalities), presence of children, education level (4 modalities), unemployment spells over the previous five years, seniority (3 modalities), part-time job, temporary contract, firm size (3 modalities), economic sector (3 modalities) and country dummies.

In what follows, the sample is restricted to occupied wage-earners, i.e. respondents claiming that they have done paid work over the past 7 days. We choose to exclude inactive, self-employed, and unemployed respondents given our focus on perceived job security. Furthermore, we only include respondents aged from 18 to 64 years, which leaves us with a sample of 11,362 individuals.

According to the ESS data, job security is viewed as at least important by more than $85 \%$ of European wage-earners. Our hypotheses regarding the importance of job security are tested by using a bivariate ordered Probit model since the two outcomes, perceived job security and its importance, are given by ordered categorical variables. Each dependent variable is expressed as a linear function of a set of individual characteristics, job characteristics, country dummies and a residual. Both residuals are supposed to follow a bivariate normal distribution. The model was estimated using a maximum likelihood method. The bivariate ordered Probit model and the corresponding likelihood function are described in Sajaia (2010). This model offers the possibility of seeing how, once individual characteristics, job characteristics, and country are controlled for, the same unobserved factors influence the two dependent variables. A simple ordered Probit model also offers the possibility to verify the assumption that employees are looking for more security in their choice of employment when their perceived job security is weak. In this latter, the perceived job security is a predictor of the importance of job security.

In each model, we include a set of country specific dummies. For the perceived job security, these fixed effects indicate the propensity for an employee to feel secure in his/her job once individual and professional characteristics are controlled for. These dummies should thus account for institutional differences in labour markets across European countries. By definition, the macroeconomic and labour market institutions variables cannot be included in 
the model since we have only one observation per country for each macroeconomic and labour market institutions variables. These factors are simply picked up by the country fixed effects.

\section{Empirical results}

We first study the relationship between perceived job security and demographic, economic and employment factors as well as macroeconomic and institutional settings. Then, following Greenhalgh \& Rosenblatt (1984), we test whether employees look for more security in their choice of employment when their perceived job security is weak. Finally, we study the factors influencing the importance of job security.

\subsection{The determinants of perceived job security}

Estimates in Table 1 suggest a decreasing age pattern for perceived job security. Gender is not correlated with perceived job security. Being married and the presence of children have no effect on perceived job security. According to the data, more educated respondents perceive more job security.

Unemployment spells (over the previous 5 years) may reduce perceived job security. This correlation appears relatively strong. Seniority is positively related to perceived job security. The probability of job exit decreases with seniority and employees take the protective effects of seniority into account. A long tenure may indicate a high level of firmspecific human capital.

Part time employment is positively correlated with perceived job security, as in Böckerman (2004) $)^{7}$. As part-time jobs are more concentrated in sectors characterized by lower probability of unemployment, this is likely to increase the perception of job security. For instance, public services offer a large proportion of part-time work where the perceived job security is relatively high. Firms have increasingly opted for this type of work arrangement (Tilly, 1996). If part-time employment is associated with new work organisations, part-time workers may feel more confident about their job security. Temporary workers report a lower perceived job security, which seems quite intuitive (see Clark and Postel-Vinay, 2009). Temporary employment is likely to induce a less favourable perception of the stability of current employment. 


\begin{tabular}{|c|c|c|c|c|c|c|}
\hline \multirow{2}{*}{ Explanatory variables } & \multicolumn{3}{|c|}{ Perceived job security } & \multicolumn{3}{|c|}{ Importance of job security } \\
\hline & coef. & t-test & $\begin{array}{l}\text { Country } \\
\text { ranking }\end{array}$ & coef. & t-test & $\begin{array}{l}\text { Country } \\
\text { ranking }\end{array}$ \\
\hline $\begin{array}{c}\text { Individual characteristics } \\
\text { Female }\end{array}$ & 0.007 & $(0.33)$ & & $0.109 * * *$ & $(4.64)$ & \\
\hline Age $\quad 25-34$ & $-0.187 * * *$ & $(4.23)$ & & -0.020 & $(0.43)$ & \\
\hline (Ref: 18-24) & $-0.300 * * *$ & $(6.43)$ & & $-0.111^{* *}$ & $(2.22)$ & \\
\hline $45-64$ & $-0.201 * * *$ & $(4.26)$ & & $-0.139 * * *$ & $(2.77)$ & \\
\hline Being married & -0.025 & $(1.00)$ & & $-0.045^{*}$ & $(1.74)$ & \\
\hline Having children & 0.017 & $(0.71)$ & & $0.062 * *$ & $(2.44)$ & \\
\hline Secondary & 0.028 & $(0.75)$ & & $-0.131 * * *$ & $(3.18)$ & \\
\hline (Ref: primary) Tertiary - short & $0.141 * * *$ & $(3.33)$ & & $-0.358 * * *$ & $(7.82)$ & \\
\hline $\begin{array}{c}\text { Tertiary - long } \\
\text { Emplovment characteristics }\end{array}$ & $0.147 * * *$ & $(2.78)$ & & $-0.527 * * *$ & $(9.50)$ & \\
\hline Unemployment spells & $-0.307 * * *$ & $(8.40)$ & & $0.066^{*}$ & $(1.70)$ & \\
\hline Seniority 3-7 years & $0.052 *$ & (1.69) & & 0.005 & $(0.16)$ & \\
\hline (Ref: 0-3 years) More than 7 years & $0.176^{* * *}$ & $(5.50)$ & & $0.174 * * *$ & $(5.14)$ & \\
\hline Part time job & $0.158 * * *$ & $(4.85)$ & & $-0.113 * * *$ & $(3.35)$ & \\
\hline Temporary contract & $-0.662 * * *$ & (19.35) & & $-0.123 * * *$ & $(3.41)$ & \\
\hline 25-99 employees & $0.068 * * *$ & $(2.59)$ & & 0.034 & $(1.24)$ & \\
\hline More than $99 \mathrm{emp}$. & 0.003 & $(0.13)$ & & $0.072 * * *$ & $(2.68)$ & \\
\hline Economic sector Secondary & -0.074 & $(1.53)$ & & -0.048 & $(0.91)$ & \\
\hline (Ref: primary) Tertiary & $0.153 * * *$ & $(3.20)$ & & -0.057 & $(1.09)$ & \\
\hline $\begin{array}{l}\text { Country effects } \\
\text { (Ref. Austria) }\end{array}$ & Ref. & & 11 & Ref. & & 7 \\
\hline Switzerland & $0.308 * * *$ & $(5.30)$ & 4 & $-0.217 * * *$ & $(3.57)$ & 12 \\
\hline Belgium & $0.160 * * *$ & $(2.63)$ & 7 & -0.034 & $(0.54)$ & 8 \\
\hline Denmark & 0.004 & $(0.07)$ & 10 & $-0.883 * * *$ & (13.69) & 18 \\
\hline Germany & $-0.416^{* * *}$ & (7.49) & 17 & $0.321 * * *$ & $(5.29)$ & 4 \\
\hline Spain & $0.179 * * *$ & $(2.81)$ & 5 & $0.432 * * *$ & $(6.17)$ & 2 \\
\hline Finland & $0.161 * * *$ & $(2.78)$ & 6 & $-0.220 * * *$ & $(3.62)$ & 13 \\
\hline France & $-0.603 * * *$ & $(9.27)$ & 18 & $-0.280 * * *$ & $(4.10)$ & 15 \\
\hline The United Kingdom & 0.093 & $(1.46)$ & 8 & $-0.170 * *$ & $(2.53)$ & 9 \\
\hline Greece & $-0.151 * *$ & $(2.10)$ & 15 & $0.810 * * *$ & $(9.44)$ & 1 \\
\hline Ireland & $0.321 * * *$ & $(4.84)$ & 3 & 0.079 & $(1.13)$ & 6 \\
\hline Iceland & $0.566 * * *$ & $(5.92)$ & 1 & $-0.223 * *$ & $(2.35)$ & 14 \\
\hline Luxembourg & $0.360 * * *$ & $(5.55)$ & 2 & $0.329 * * *$ & $(4.73)$ & 3 \\
\hline The Netherlands & $-0.221 * * *$ & $(3.72)$ & 16 & $-0.499 * * *$ & $(7.93)$ & 17 \\
\hline Norway & 0.029 & $(0.50)$ & 9 & $-0.174 * * *$ & $(2.88)$ & 10 \\
\hline Portugal & $-0.145^{* *}$ & $(2.18)$ & 14 & $0.213 * * *$ & $(2.90)$ & 5 \\
\hline Sweden & -0.020 & $(0.35)$ & 13 & $-0.369 * * *$ & $(6.26)$ & 16 \\
\hline Slovenia & -0.009 & $(0.12)$ & 12 & $-0.187 * *$ & $(2.48)$ & 11 \\
\hline $\begin{array}{l}\text { Coefficient of correlation (t-tes } \\
\text { Log likelihood }\end{array}$ & & & & $\begin{array}{l}* *(9.53) \\
594.9\end{array}$ & & \\
\hline
\end{tabular}

\section{TABLE 1}

\section{Determinants of perceived job security and importance of job security}

Source: ESS 2004-2005.

Note: Estimates are from a Bivariate ordered Probit model, estimated by a maximum likelihood method. The sample is restricted to wage-earners aged between 18 and 64 (11362 observations). Absolute values of t-values are in parentheses, significance levels being equal to $1 \%(* * *), 5 \%(* *)$ and $10 \%(*)$. The column 'Country ranking' corresponds to the rank associated to the various country fixed effects, a low ranking being associated to a large country coefficient. 
The perceived job security is positively connected with medium-sized firms (between 25 and 99 wage-earners). This result is partly in accordance with the models of job turnover for which the turnover decreases with the size of the firm (Davis and Haltiwanger, 1999). Perceived job security is higher in service sector than in the other sectors, whereas primary and secondary sectors do not exhibit significant differences.

We also include country-specific dummy variables in the bivariate model, Austria being the reference country. These fixed effects indicate the propensity for a worker to feel secure in his/her job once individual and professional characteristics are taken into account. They should thus account for institutional differences in labour markets across European countries, especially with respect to employment protection legislation. We rank the fixed effects in each country and assign a rank each country between 1 and 18 . Low values are for countries where perceived job security is substantially higher. As shown in Table 1, the perceived job security is lower in mainland European countries like France and Germany and in the Southern countries (except for Spain). It is highest in Iceland, Luxembourg, and in Ireland.

As shown in previous studies (Böckerman, 2004; Postel-Vinay and Saint-Martin, 2005; Clark and Postel-Vinay, 2009), macro-economic indicators and institutional factors influence perceived job security in Europe. At the macro level, the business cycle and institutional factors are also expected to affect the importance of job security in the choice of employment. In Figure 2, the country fixed effects measuring the perceived job security have been plotted with several economic and labour market institution indicators. 
County fixed effects

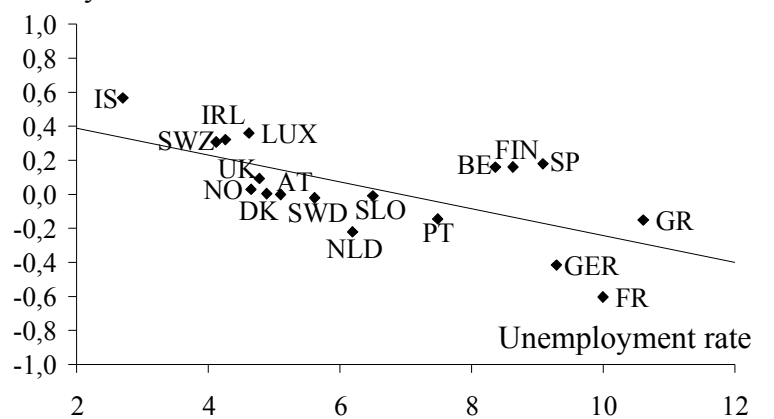

Country fixed effects

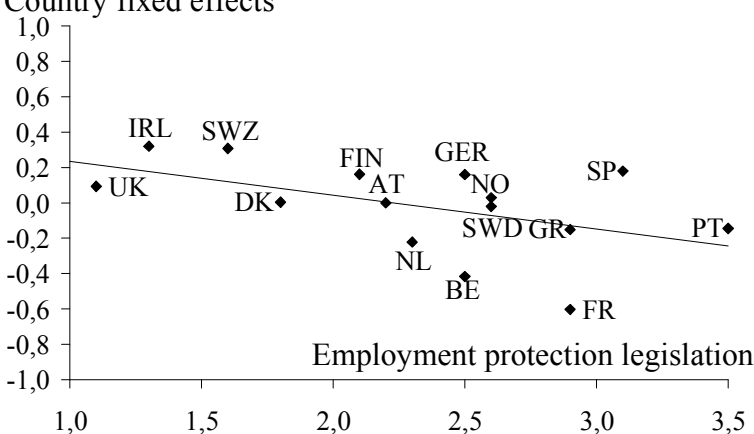

Country fixed effects

1,0

0,8

:

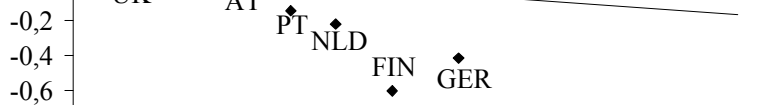

$-0,6$

$-1,0$

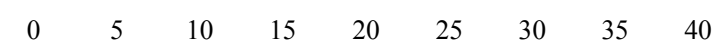

Country fixed effects

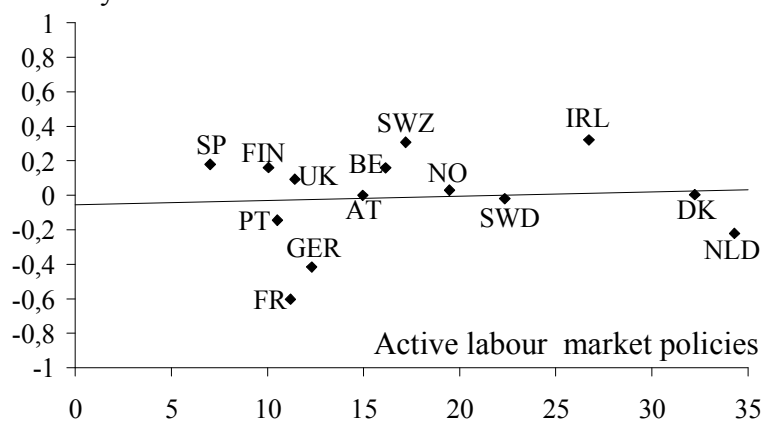

FIGURE 1

Country fixed effects of the perceived job security according to unemployment and labour market indicators

Source: ESS 2004-2005 and OECD (2007).

Notes: The job security coefficients are given by the country fixed effects reported in Table 1, Austria being the reference country. The country fixed effects measure the perceived job security net of individual and employment characteristics.

Data on unemployment insurance generosity are missing for Iceland, Greece, Luxembourg and Slovenia.

Data on employment protection legislation are missing for Iceland, Luxembourg and Slovenia.

Expenditures on Active Labour Market Policies are divided by the Unemployment Rate in 2003, so that they are expressed as Expenditures on Active Labour Market Policies per unemployed individual normalised on GDP per member of the labour force. Data on active labour market policies are missing for Iceland, Greece, Luxembourg, and Slovenia.

As expected, we evidence a negative correlation between the unemployment rate in the selected countries and the perceived of job security. In countries where the economic situation is prone to induce a high unemployment rate, employees seem to have lower perceived job security. We also consider the potential role of unemployment insurance benefits using the indicator described in Allard (2005), which combines the amount of benefits with its tax treatment, its duration and the conditions necessary for eligibility. We find an insignificant negative correlation between unemployment insurance generosity and country fixed effects associated to perceived job security.

The level of labour market regulation also influences the perceived job security. In Figure 2, we evidence a negative correlation across countries between employment protection legislation and the country fixed effects attributed to the perceived job security. In countries where the employment protection legislation is strict (labour market regulation is important), 
employees perceive lower job security. This perception may be lower because they consider that it is more difficult to find a job in such countries as the permeability of the barrier between employment and unemployment is lower.

We also consider the relationship between the ratio of active labour market policy expenditure to the unemployment rate and the country fixed effects assigned to the perception of job security. Active labour market policies refer to programmes whose aim is to facilitate re-entry into the labour market. We find that individuals perceive a higher job security in countries characterized by a relatively high level of active labour market policies, but the correlation is not strongly significant.

\subsection{From the perceived job security to its importance}

We describe the relationship between perceived job security and its importance in Figure 2. Using mean values by country, we find a positive but insignificant relationship between these two outcomes. At the individual level, perceived job security is introduced in an ordered Probit regression as an additional predictor of the importance attached to security (see Table 2).

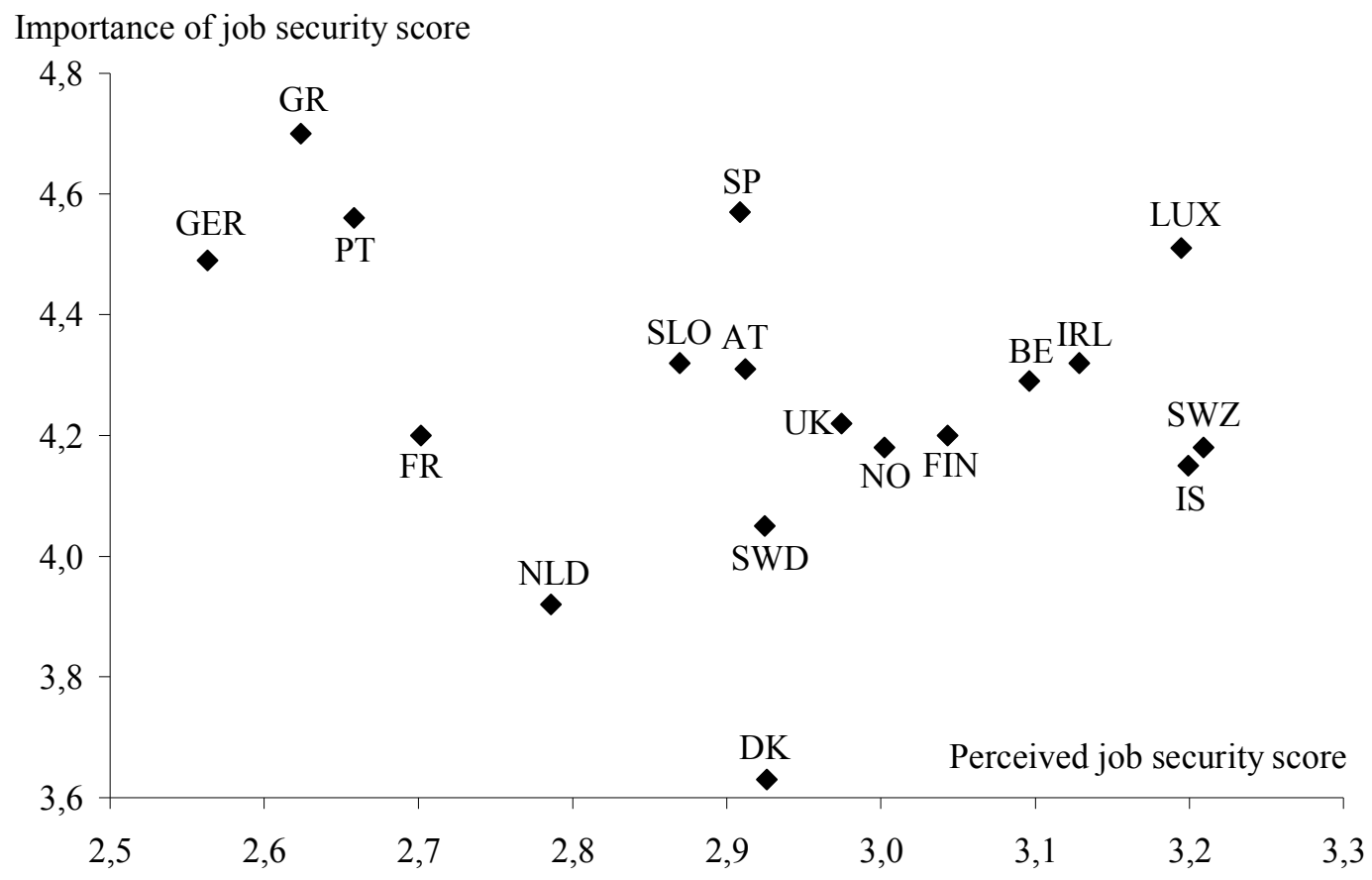

FIGURE 2

Importance of job security and perceived job security

Source: ESS 2004-2005.

Note: The importance of job security score is given by the mean answer to the question about the importance of job security, ranging from 1 ('not important at all') to 5 ('very important). The perceived job security score is given by the mean answer to the question about the perceived job security of current employment, ranging from 1 to 4 ('not at all true', 'a little true', 'quite true', and 'very true'). 
Our expectation is not verified. Employees characterized by a low probability of job loss (measured through the answers 'quite true' and 'very true') place more value to job security than the others when choosing a job. Workers who assess that job security is important may have worked to get themselves into 'objectively' safer jobs (for instance permanent jobs). This self-selection into job types may be dependent on the workers (unobserved) general attitudes toward job security and its importance ${ }^{8}$.

\begin{tabular}{|c|cc|}
\hline \multirow{2}{*}{ Explanatory variables } & \multicolumn{2}{|c|}{ Importance of job security } \\
\cline { 2 - 3 } & \multicolumn{2}{|c|}{ coefficients } \\
\hline Perceived job security & \multicolumn{2}{|c|}{ Ref. } \\
Not at all true & -0.037 & $(0.88)$ \\
A little true & $0.072^{*}$ & $(1.86)$ \\
Quite true & $0.270^{* * *}$ & $(6.74)$ \\
Very true & \multicolumn{2}{|c|}{-10742.247} \\
\hline Log likelihood
\end{tabular}

TABLE 2

Determinants of importance of job security

Source: ESS 2004-2005.

Note: Estimates are from an ordered Probit model, estimated by a maximum likelihood method. The sample is restricted to wage-earners aged between 18 and 64 (11362 observations). Absolute values of t-values are in parentheses, significance levels being equal to $1 \%(* *), 5 \%(* *)$ and $10 \%(*)$. The model also includes variables related to gender, age, marital status, children, education, seniority, part-time, temporary contract, firm size, economic sector, and country dummies.

\subsection{The importance of job security}

First, we evidence an inverse relation between age and importance of job security when choosing employment (Table 1). Older workers (especially above 45 years) put less importance on job security in their employment choice. Facing lower exit rates of unemployment, it could be that older workers are less demanding as they compete with younger individuals who just have completed their education and seek to enter the labour market. Also, older workers may take their family constraints into greater consideration when having to choose a job.

Surprisingly, the importance of job security is higher for women than for men. One possible explanation is that men are more career-oriented, therefore being more interested in receiving wage increases and promotions than just having a secure job, while women prioritize other values such as family and being in a secure job environment (Hakim, 1996). Being married and the number of children affect the importance given to job security. We find 
a negative correlation between being married and the importance of job security, certainly because of the cohesive power of marriage. Conversely, we obtain a positive coefficient for the presence of children living within the household. Parental responsibility, especially through financial support, influences the importance attributed to job security.

There is a negative correlation between education and the importance of job security in employment choice, which could be explained by the higher propensity for highly educated individuals to find a job. The different factors reflecting the employment history strongly influence the importance attributed to job security in the choice of employment. Unemployment spells (over the previous 5 years) are positively correlated with its importance. Being unemployed may induce a kind of 'scarring' effect enhancing the importance of job security.

Seniority is positively related to the importance of job security, but this result holds only when seniority exceeds 7 years. This could be linked to the willingness of respondents to work on a long-term employment relationship. Part time employment is negatively correlated with the importance of job security. The lower importance of job security reported by parttime workers could be due to the influence of other factors such as family considerations (O’Reilly and Fagan, 1998). Temporary workers report a lower importance given to job security. Permanents and temporaries hold different prospects regarding their work arrangements (De Cuyper and De Witte, 2006). Using the psychological contracts framework, De Cuyper and De Witte (2006) show that job security has been proved more problematic for permanents than for temporaries due to the type of employment relationship which is more transactional in this latter case, whereas there are more relational promises among permanent jobs. Concerning the firm size, the importance of job security is higher in great sized-firms. This result may be due to the higher turnover existing in such organisations. Economic sectors have no significant influence on the importance of job security.

Concerning the country fixed effects, the importance of job security on employment decisions is relatively high in Southern countries (Greece, Spain, and Portugal) and in some other mainland European countries (Luxembourg, and Germany). Conversely, Northern countries (Denmark, Netherlands, Sweden, Finland, and to a lesser extent Norway) and France are characterized by a lower propensity to consider job security as important in the choice of employment. We find that the rank associated with the importance of job security is much lower than the rank assigned to the perceived job security in Greece, in Portugal and in Germany. The reverse pattern is true in Denmark, Ireland, Switzerland and the Netherlands. 
At the macro level, the economic situation and institutional settings are also expected to affect the importance of job security in the choice of employment. In Figure 3, the country fixed effects measuring the importance of job security have been plotted with several economic and labour market institution indicators.
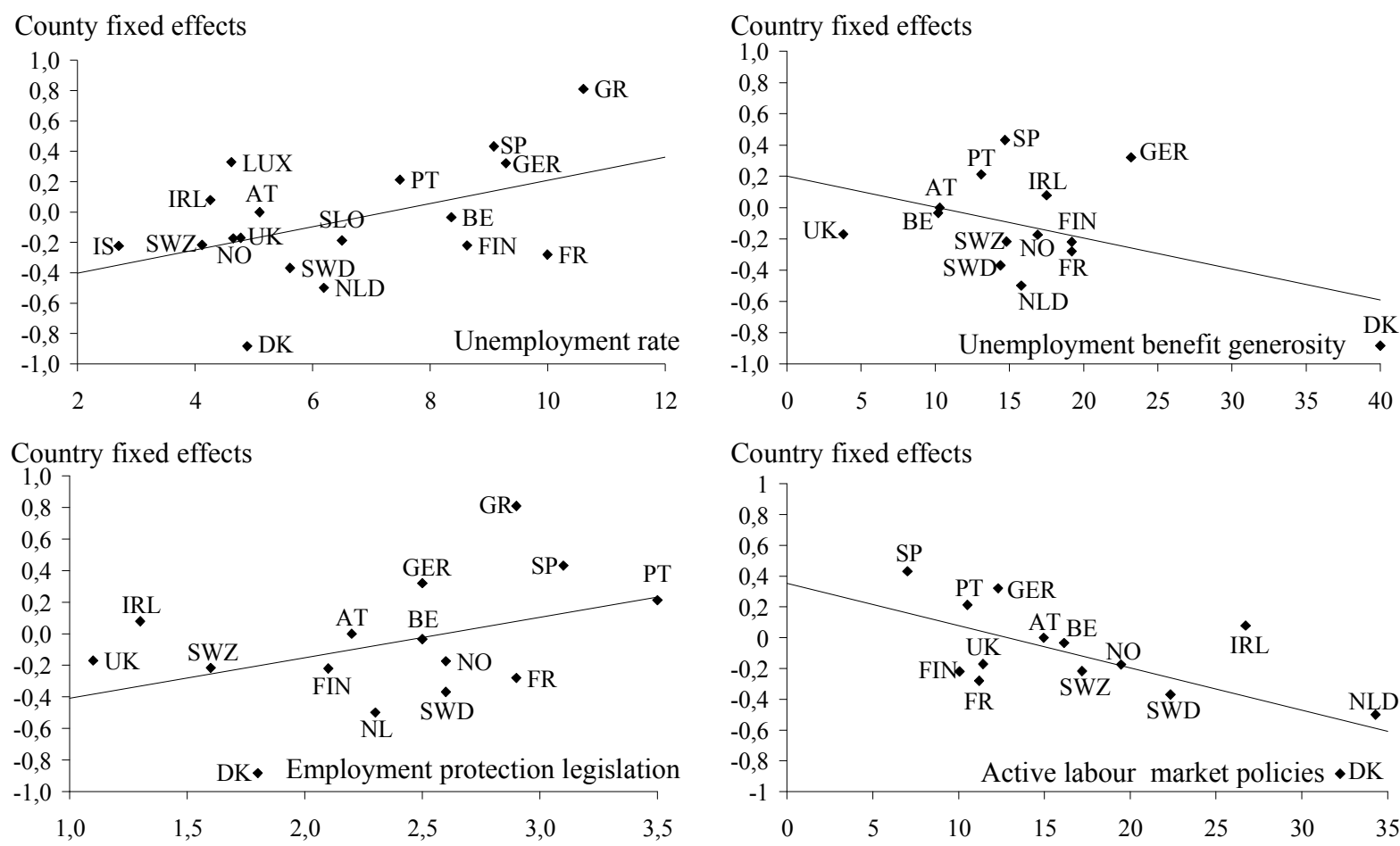

Country fixed effects

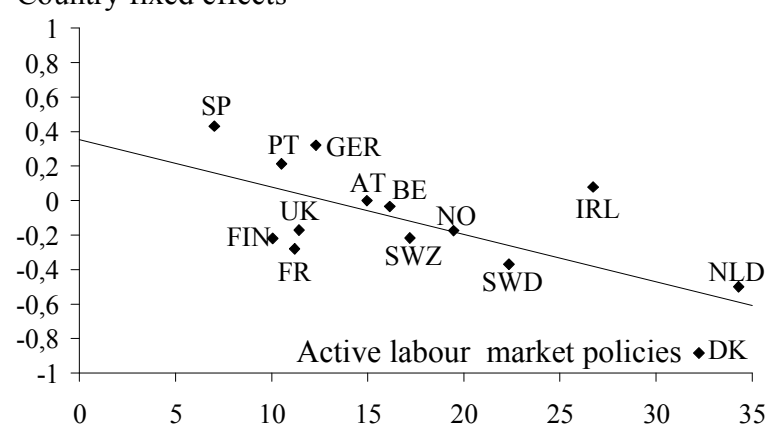

FIGURE 3

Country fixed effects of the importance of job security according to unemployment rate and labour market institution indicators

Source: ESS 2004-2005 and OECD (2007).

Notes: The job security coefficients are given by the country fixed effects reported in Table 1, Austria being the reference country. The country fixed effects measure the importance of job security net of individual and employment characteristics.

Data on unemployment insurance generosity are missing for Iceland, Greece, Luxembourg and Slovenia.

Data on employment protection legislation are missing for Iceland, Luxembourg and Slovenia.

Expenditures on Active Labour Market Policies are divided by the Unemployment Rate in 2003, so that they are expressed as Expenditures on Active Labour Market Policies per unemployed individual normalised on GDP per member of the labour force. Data on active labour market policies are missing for Iceland, Greece, Luxembourg, and Slovenia.

We evidence a positive correlation between the unemployment rate in the selected countries and the importance of job security. In countries where the economic situation is prone to induce a high unemployment rate, employees seem to attach more importance to job security. We also consider the potential role of unemployment insurance benefits. We find a significant correlation between unemployment insurance generosity and country fixed effects given to the importance of job security. In countries where unemployment insurance generosity is high, individuals attribute a lower importance to job security in the choice of employment ${ }^{9}$. 
The level of labour market regulation also influences the importance of job security. As shown in Figure 3, we find a positive correlation between employment protection legislation and the country fixed effects attributed to the importance of job security. In countries where the employment protection legislation is strict (labour market regulation is important), employees attach more importance to job security. This importance may be higher because they consider that it is more difficult to find a job in such countries as the permeability of the barrier between employment and unemployment is lower.

We also consider the relationship between the ratio of active labour market policy expenditures to the unemployment rate and the country fixed effects assigned to the importance of job security. Active labour market policies refer to programmes whose aim is to facilitate re-entry into the labour market. We find that individuals report a lower importance allotted to job security in countries characterized by a relatively high level of active labour market policies, the correlation being highly significant ${ }^{10}$.

\section{Discussion}

The purpose of our study was to analyze the factors influencing the importance of job security in a European perspective using recent data from the ESS survey. This study tested the hypotheses that the weaker perceived job security is, the more the employees attach importance to job security in the choice of employment, and that the importance of job security is related to individual characteristics, job characteristics, the economic situation and labour market institutions (and is not purely subjective). While our first expectation is not verified (perceived job security and its importance are in fact positively correlated), both individual and job characteristics as well as economic and institutional settings do have an impact on the importance of job security.

Contrary to our expectations, employees who have a low probability of job loss value job security more than others when choosing a job. This self-selection into work arrangements may depend on the workers' attitudes toward job security and its importance. Several individual and employment characteristics have a similar impact on both perceived job security and its importance. Firstly, we evidence a decreasing age pattern for both perceived job security and its importance when choosing a job (this result holds only when age is above 35 years). Secondly, seniority is positively related to perceived job security and its importance (at least when seniority exceeds 7 years). Thirdly, temporary workers report a lower perceived job security, which is quite intuitive, while having a temporary contract reduces the importance of job security. 
Several individual and employment characteristics have an opposite impact on perceived job security and its importance. Firstly, tertiary education increases perceived job security and reduces its importance, which could be explained by the higher propensity for high educated individuals to keep and find a job. Secondly, unemployment spell (during the last 5 years) reduces the perceived job security, while it is positively correlated with its importance. Thirdly, as part-time jobs are more concentrated in sectors characterized by lower unemployment probability, this is likely to increase the perception attributed to job security. At the same time, the lower importance of job security reported by part-time workers could be due to the influence of other factors like family considerations.

Several additional results have to be noticed. Being married tends to reduce the importance attributed to job security, while the presence of children increases it. Surprisingly, men report a lower attachment to job security than women. Beyond the explicatory factors suggested below, this may be linked to other macro factors such as the higher female unemployment rate in the great majority of European countries. In countries where the economic situation is prone to inducing a high unemployment rate and where unemployment benefit generosity is low and active labour market policies are weak, employees seem to attach more importance to job security. This importance is low in countries where employment protection legislation is weak. It seems easier to find a job in such countries where lower barriers between employment and unemployment exist.

Finally, there are some drawbacks to this study. First, it would be better to rely on a longitudinal database. The role of macroeconomic and institutional settings has been investigated only across countries and not over time. We are then not able to say if the importance of job security is linked to the business cycle or not. Nevertheless, labour market institutions are relatively stable (see Nickell et al., 2005). another drawback is the comparability issue. As ordered subjective assessments of job security and its importance may not be perfectly comparable across the different countries, it would be worthwhile trying to account for differences in reporting styles and specific influence of the functioning of the labour markets to further compare the importance of job security when choosing a job between European countries.

While there are large differences between the countries under consideration in ouyr study, the importance of job security in the choice of employment is viewed as important by a large majority of European workers. This study and its results have practical and political implications. Flexicurity is about successful moves or transitions over one's life, from school to work, from one job to another, between unemployment/inactivity and work, and from work 
to retirement (European Commission, 2007). According to our results, the emphasis put on flexicurity approaches is not really in line with the expectations of European employees as job security appears relatively important to them. Nonetheless, flexible labour markets, like the Danish one, tend have a lower importance allotted to job security. 


\section{References}

Aaronson, D. and D.G. Sullivan (1998) 'The decline in job security in the 1990s: displacement, anxiety, and their effect on wage growth', Federal Bank of Chicago (22): 17-43.

Allard, G. (2005) 'Measuring the changing generosity of unemployment benefits: Beyond existing indicators', mimeo, Instituto de Empressa Working Paper WP-05.

Anderson, C.J. and J. Pontusson (2007) 'Workers, Worries and Welfare States: Social Protection and Job Insecurity in 15 OECD Countries', European Journal of Political Research 46(2): 211-235.

Anxo, D. (2003) 'Division sexuelle des tâches : les expériences françaises et suédoises', Futuribles 285: 33-40.

Arulampalam, W., P. Gregg and M. Gregory (2001) 'Unemployment scarring', Economic Journal 111(475): 577-584.

Ashford, S.J., C. Lee and P. Bobko (1989) 'Content, causes, and consequences of job insecurity: a theory-based measure and substantive test', Academy of Management Journal 32(4): 803-29.

Blanchflower, D. and A.J. Oswald (1999) 'Well-Being, insecurity and the decline of American job satisfaction', mimeo, University of Warwick, Coventry.

Böckerman, P. (2004) 'Perception of job instability in Europe', Social Indicators Research 67(3): 283-314.

Bohle, P., M. Quinlan and C. Mayhew (2001) 'The health and safety effects of job insecurity: An evaluation of the evidence', Economic and Labour Relations Review 12(1): 32-60.

Boone, J. and J. Van Ours (2004) 'Effective active labor market policies', IZA Discussion Paper 1335.

Borg I. and D. Elizur (1992), 'Job Insecurity: Correlates, Moderators and Measurement', International Journal of Manpower 13(2): 13-26.

Clark, A. and F. Postel-Vinay (2009) 'Job security and job protection', Oxford Economic Papers, 61(2):207-239.

Coleman, J. (1986) 'Social Theory, Social Research, and a Theory of Action', American Journal of Sociology 91(6):1309-1335.

D'Addio, A., T. Eriksson and P. Frijters (2007) 'An analysis of the determinants of job satisfaction when individuals baseline satisfaction levels may differ', Applied Economics 39(19): 2413-2423.

Davis, S.J. and J. Haltiwanger (1999) 'Gross job flows', in Ashenfelter, O. and D. Card (eds.), Handbook of Labour Economics (3C): 2711-2805, North-Holland, Amsterdam.

De Cuyper, N. and H. De Witte (2006) 'The impact of job insecurity and contract type on attitudes, well-being and behavioural reports: A psychological contract perspective', Journal of Occupational and Organizational Psychology 79: 395-409.

De Witte, H. (1999) 'Job insecurity and psychological well-being: Review of the literature and exploration of some unresolved issues', European Journal of work and Organizational psychology 8(2): 155-177. 
Erlinghagen, M. (2008) 'Self-perceived job insecurity and social context: A multi-level analysis of 17 European countries', European Sociological Review 24(2): 183-97.

European Commission (2007) Towards Common Principles of Flexicurity: More and better jobs through flexibility and security, Bruxelles: COM(2007)359.

Green, F., D. Campbell, A. Carruth and A. Dickerson (2001) 'An analysis of subjective views of job insecurity', mimeo, University of Kent, Canterbury.

Greenhalgh, L., Z. Rosenblatt (2010) 'Evolution of Research on Job Insecurity', International Studies of Management and Organization 40(1): 6-19.

Greenhalgh, L., Z. Rosenblatt (1984) 'Job insecurity: Toward conceptual clarity', Academy of Management Review 9: 438-448.

Hakim, C. (1996) Key issues in women's employment. London: Athlone.

Lewis, J. (2002) 'Gender and Welfare State Change', European Societies 4(4): 331-357.

Madsen, P.K. (2004) 'The Danish model of 'flexicurity': Experiences and lessons', Transfer, European Review of Labour and Research 10(2): 187-207.

Nickell, S., L. Nunziata, and W. Ochel (2005) 'Unemployment in the OECD countries since the 1960s: what do we know?', The Economic Journal 115(500): 1-27.

Nunziata, L. and S. Staffolani (2007) 'Short term contracts regulations and dynamic labour demand: Theory and evidence', Scottish Journal of Political Economy 54(1): 72-104.

OECD (2002) Employment Outlook, Paris.

OECD (2003) Employment Outlook, Paris.

OECD (2007) Labour force Survey, Paris.

Oorschot, Van W. (2004) 'Flexible work and flexicurity policies in the Netherlands: Trends and experiences', Transfer, European Review of Labour and Research 10(2): 208-225.

O'Reilly J. and C. Fagan (1998) Part-time prospects: an international comparison of parttime work in Europe, North America and the Pacific Rim. London: Routledge.

Postel-Vinay, F. and A. Saint-Martin (2005) 'Comment les salariés perçoivent-ils la protection de 1'emploi ?', Economie et Statistique (372): 41-59.

Sajaia, Z. (2010) 'Maximum likelihood estimation of a bivariate ordered Probit model: Implementation and Monte Carlo simulations', Stata Journal, forthcoming.

Sverke M. and J. Hellgreen (2002), 'The Nature of Job Insecurity: Understanding Employment Uncertainty on the Brink of a New Millennium', Applied Psychology: An International Review 51(1): 23-42.

Sverke, M., J. Hellgren and K. Näswall (2002) 'No security: A meta-analysis and review of job security and its consequences', Journal of Occupational Health Psychology 7(3): 242-264.

Tilly, C. (1996) Half a job: Bad and good part-time in changing labor markets. Philadelphia: Temple University Press.

Westman, M., D. Etzion and E. Danon (2001) 'Job insecurity and crossover of burnout in married couples', Journal of Organizational Behavior 22(5): 467-481. 
Wilthagen, T. and F. Tros (2004) 'The concept of 'flexicurity': a new approach to regulating employment and labour markets', Transfer, European Review of Labour and Research 10(2): 166-186.

Wilthagen, T., F.H. Tros and H. Van Lieshout (2004) 'Towards 'flexicurity'? Balancing flexibility and security in EU Member States', European Journal of Social Security 6(2): 113-136. 
${ }^{1}$ In the majority of the OECD countries, perceived job security was characterized by a notable deterioration during the nineties (OECD, 2003).

${ }^{2}$ According to the European Commission (2007), "flexicurity aims at ensuring that EU citizens can enjoy a high level of employment security, i.e. the possibility of easily finding a job at every stage of active life and have a good prospect for career development in a quickly changing economic environment".

${ }^{3}$ The index of strictness of EPL defined by OECD (2007) is based on several factors: the norms of notice periods and severance pay for individual and collective dismissals, compensation pay and related provisions following unjustified dismissals, and the number and duration of allowed successive temporary contracts, among others. The score of each country ranges from 0 (weak or no legislation) to 4 (strict legislation).

${ }^{4}$ Active labour market policies include programmes such as public employment services, labour market training, start-up incentives, job rotation and job sharing (Boone and Van Ours, 2004).

${ }^{5}$ In the psychological contract perspective, temporary employment can be perceived by workers as a transactional psychological contract (with narrow and short term relationships focusing on economic exchange). An alternative way to understand the subjective perceptions of mutual expectations and obligations between employers and employees is to consider the psychological contract in a relational perspective. Nevertheless, De Cuyper and De Witte (2006, p.405) did not find "clear-cut differences between temporaries and permanents on job satisfaction, life satisfaction, organizational commitment, and self-rated performance". They conclude that job insecurity is expected to be problematic in terms of outcomes for permanents, but not for temporaries.

${ }^{6}$ Note that we choose to exclude respondents from Eastern countries (in particular Poland, Czech Republic, Hungary, Slovakia, Ukraine, and Estonia) in order to study more homogeneous countries with respect to their labour markets and institutional features.

${ }^{7}$ In line with OECD (2002), we define part-time as a job for which number of hours worked per week does not exceed 30 hours.

${ }^{8}$ Once the individual characteristics, job characteristics and country fixed effects are controlled for, we find a positive coefficient of correlation between the two residuals. This suggests that the same unobserved factors influence in the same way the two dependent variables.

${ }^{9}$ Once again, the Danish case is characterised by a particular situation that combines high unemployment benefit generosity and low importance attributed to job security compared to other countries.

${ }^{10}$ Both for employment protection legislation and active labour market policies, we note the very particular situation of Denmark. 